\title{
Blockholder Ownership Impact on the Related Party Transactions to the Financial Industries
}

\section{Supatmi ${ }^{*}$, Ines Aprilia Primadani ${ }^{2}$}

1,2 Universitas Kristen Satya Wacana, Salatiga, Indonesia

\section{ART ICLE INFO}

Article history:

Received April 01, 2021

Revised April 03, 2021

Accepted May 01, 2021

Available online May 25, 2021

\section{Keywords:}

Blockholder ownership, Related party transactions, Tunnelling



This is an open access article under the CC BY-SA license.

Copyright $@ 2021$ by Author. Published by Universitas Pendidikan Ganesha.

\begin{abstract}
A B S T R A C T
Research on the impact of ownership structure on related party transactions carried out by companies gives varied results. Moreover, this research still rarely uses a sample of the financial industry in Indonesia. So, the study aimed to find out block holder ownership effect on tunnelling or propping related party transactions in financial industries in Indonesia. Sample research were 82 financial industries that listed in Indonesian Stock Exchange in 2017-2019 with 246 observations as panel data. Based on panel data regression test, this study found block holder ownership had positive effects on tunnelling related party transactions that proxied by related party transactions related to accounts receivable and related party transactions related to assets other than account receivables. Meanwhile, blockholder ownership had no effect on propping related party transactions that proxied by related party transactions related to accounts payable and liabilities other than accounts payable. The study also found blockholder ownership effect on tunnelling related party transactions was bigger than propping. These findings were appropriate with the relevant agency theory about blockholder ownership effect on related party transactions which had the potency on the emergence of agency conflict among the shareholders.
\end{abstract}

\section{INTRODUCTION}

Business implementations in Indonesian companies commonly are related to each other because connection with related parties becomes a normal characteristic in the business and transactions possibility with the related parties will be higher when it is compared to transactions with unrelated parties (Helena \& Firmansyah, 2018). Related parties can be interpreted as an entity that is connected to other entities which prepares financial reports and a party is said having a relation if the party can affect other parties in running the businesses. There are two alternative explanations about related party transactions. First, according to the transaction cost theory, related party transaction is considered efficient because it may reduce cost and it can overcome difficulties in rights and contracts (Bona-Sánchez et al., 2017). Further, according to the agency theory, related party transactions is assumed as an opportunistic that may influence the company value negatively because it creates chances for the insiders to dig resources outside.

Majority companies in Indonesia use concentrated ownership structure (Pangesti \& Hidayat, 2019). There are about $71 \%$ of company cases in Indonesia that are managed and concentrated to the family (Herliana, 2018). Moreover, family ownership may cause strong controlling from the family members or business partners to the management (Herliana, 2018). With this family concentrated structure then many companies are interconnected on the ownership among parent companies, subsidiaries, or branches (Helena \& Firmansyah, 2018). This condition may strengthen the appearance of transactions on the parties which have relations.

There is a relationship between related party transactions and controlling shareholders in public companies in China (Cheung et al., 2009). The results of this study prove that blockholder ownership uses related party transactions to take over the rights of minority shareholders through tunnelling and propping. Companies registered in China carried out more tunnelling than propping related party transactions (Cheung et al., 2009). Tunnelling is an activity of transferring the wealth of a company to another company that has control over the company (Brundy \& Siswantaya, 2014). While propping is related to transfers from companies that have control to other companies that aim to help the recipient 
company prevent bankruptcy (Tambunan et al., 2013) Meanwhile, the existence of blockholder ownership resulted in the creation of a shield against law or regulation (Sun et al., 2016).

A study that was conducted on the companies that are listed in Spain which use ownership structure with the number of presence of blockholder ownership has proven that more than half of the public companies conduct related party transactions during the analyzed period (Bona-Sánchez et al., 2017). With the presence of blockholder ownership, total related party transactions that are implemented reached 99.84 percent of the transactions that are implemented in the go-public Spain companies. With the presence of majority shareholders and weak protection for minority investors, then related party transactions that are carried out by the banking sectors contain more conflict of interests than efficient transactions, or there are more tunnelling type than propping type (Supatmi et al., 2019).

The aim of this study is to find empirical evidence about impact of blockholder ownership on related party transactions to the financial industry in Indonesia during the period of 2017-2019. Financial industry is chosen with a consideration as a high-regulated industrial group that is prone to related party transactions. Besides that, financial industry has important roles in Indonesian economy especially in banking sector that is the centre of Indonesian economy (Supatmi et al., 2019). Tunnelling related party transactions will be proxied with related party transactions that is related to receivable accounts and assets other than receivable account, and propping related party transactions will be proxied with related party transactions that is related to accounts payable and liabilities other than accounts payable. This transaction is chosen because related party transaction has direct relations with the performance of financial industries that move in fund collecting and distribution field. This study formulates the hypothesis that blockholder ownership has a positive effect on related party transactions and the effect of blockholder ownership on tunnelling related party transactions is greater than propping related party transactions. The contributions of this research provide theoretical development regarding the effect of blockholder ownership on related party transactions in the financial industry in Indonesia. In addition, the results of the research can also be used as a basis for making decisions for companies in implementing related party transaction policies so as not to harm minority shareholders and as a consideration for investors when investing in a company. For policy makers, this research can be used as a consideration in terms of regulating the ownership of financial industry companies and related party transactions in the financial industry.

\section{METHODS}

This study uses financial industries that are registered in Indonesia Stock Exchange during 20172019 as the research population, with the total 82 companies. Research data uses secondary data in form of financial industries annual financial reports in 2017-2019 that are obtained from www.idx.co.id. By using purposive sampling, the samples in this study are presented in Table 1.

Table 1. Research Sample

\begin{tabular}{lc}
\hline \multicolumn{1}{c}{ Criteria } & Number of Companies \\
\hline Financial companies that are listed in ISE in 2017-2019 & 94 \\
Companies that don't publish annual report consistently & $(7)$ \\
Companies whose financial reports don't end on December 31 st & $(0)$ \\
Companies that don't have information of stock price & $(2)$ \\
Companies that don't have information about related party transactions & $(3)$ \\
\hline Total samples that meet the criterias & $\mathbf{8 2}$ \\
\hline
\end{tabular}

This study uses data from financial sector companies such as insurance companies, banking companies, and other financial companies such as consumer finance and investment companies. However, in the data test, outlier data is found therefore total number of research observations were 241 for each of dependent variable related party transactions related to accounts receivable and asset related party transactions other than accounts receivable. While the number of observations for related party transactions related to accounts payable were 237 and related party transaction related to liabilities other than accounts payable were 238. Distribution for the amount of observation in the study is presented in Table 2. Dependent variable of this study is the related party transactions that is interpreted as business transactions between the parties with special relations, meanwhile, it also serves as coalition mechanism between majority shareholders (blockholder ownership) with the management for personal importance purposes (Pangesti \& Hidayat, 2019). There are two classifications of related party transactions: tunnelling and propping (Cheung et al., 2009). Tunnelling related party transactions are measured based 
on the amount of related party transactions that are related to accounts receivable (RPT AR) or assets other than accounts receivable (RPT NAR) which are in the financial reports and they are divided by total assets of the company. Furthermore, propping related party transactions are measured based on the amount of accounts payable of related party transactions (RPT AP) or liabilities other than accounts payable (RPT NAP) which are in the financial reports and they are divided by total liabilities (Supatmi, 2020). Independent variable of this research is blockholder ownership (BO) that can be measured with the percentage of shares ownership by the biggest shareholder of the company (Sun et al., 2016). Control variables that are used is company size, leverage, and audit quality. Company size (CS) is measured by using natural log from total assets, while leverage (LV) is measured by total liabilities divided by total assets of the company by the end of the year, audit quality (AQ) is measured by giving score 1 for the companies whose financial reports are audited by the affiliated Big 4 PAF - Public Accountant Firm - and score 0 if the companies don't use affiliated Big 4 PAF

Table 2. Distribution of Amount of Research Observations per Industrial Sector

\begin{tabular}{|c|c|c|c|c|c|c|c|c|}
\hline \multirow{3}{*}{$\begin{array}{c}\text { Industr } \\
\mathbf{y}\end{array}$} & \multicolumn{4}{|c|}{ RPT Tunneling } & \multicolumn{4}{|c|}{ RPT Propping } \\
\hline & \multicolumn{2}{|c|}{ RPT AR } & \multicolumn{2}{|c|}{ RPT NAR } & \multicolumn{2}{|c|}{ RPT AP } & \multicolumn{2}{|c|}{ RPT NAP } \\
\hline & $\begin{array}{c}\text { Amou } \\
\text { nt }\end{array}$ & $\begin{array}{c}\text { Proportio } \\
\text { n }\end{array}$ & $\underset{t}{\text { Amoun }}$ & $\begin{array}{c}\text { Proportio } \\
\text { n }\end{array}$ & $\begin{array}{c}\text { Amoun } \\
t\end{array}$ & $\begin{array}{c}\text { Proportio } \\
\text { n }\end{array}$ & $\begin{array}{c}\text { Amoun } \\
t\end{array}$ & $\begin{array}{c}\text { Proportio } \\
\text { n }\end{array}$ \\
\hline Financia & 78 & $32 \%$ & 78 & $32 \%$ & 77 & $32 \%$ & 78 & $33 \%$ \\
\hline Banking & 129 & $54 \%$ & 129 & $54 \%$ & 125 & $53 \%$ & 124 & $52 \%$ \\
\hline $\begin{array}{l}\text { Insuranc } \\
\mathrm{e}\end{array}$ & 34 & $14 \%$ & 34 & $14 \%$ & 35 & $15 \%$ & 36 & $15 \%$ \\
\hline Total & 241 & $100 \%$ & 241 & $100 \%$ & 237 & $100 \%$ & 238 & $100 \%$ \\
\hline
\end{tabular}

Analysis technique that is used to test the hypothesis is panel data regression by using Eviews 9. Hypothesis acceptance (H1), which is blockholder ownership has positive effect on related party transactions in the financial industries, is stated with statistical hypothesis Ho: $\beta_{1}$ dan $\alpha_{1} \leq 0$ Ha : $\beta_{1}$ dan $\alpha_{1}>0$. Hypothesis acceptance (H2), which is blockholder ownership has effect on tunnelling related party transactions is bigger than propping related party transactions in the financial industries, statistical hypothesis stated as Ho: Adjusted $\mathrm{R}^{2}$ equation $1 \geq$ Adjusted $\mathrm{R}^{2}$ equation 2 , Ha: Adjusted $\mathrm{R}^{2}$ equation $1<$ Adjusted $\mathrm{R}^{2}$ equation 2 . Acceptance of the hypothesis using $5 \%$ confidence level.

\section{RESULTS AND DISCUSSIONS}

\section{Results}

Descriptive Statistics

Table 3 describes data distributions for each variable in this study.

Table 3. Description of Statistics

\begin{tabular}{lcccc}
\hline $\begin{array}{c}\text { Research } \\
\text { Variable }\end{array}$ & $\begin{array}{c}\text { Maximum } \\
\text { Value }\end{array}$ & $\begin{array}{c}\text { Minimum } \\
\text { Value }\end{array}$ & $\begin{array}{c}\text { Average } \\
\text { Value }\end{array}$ & $\begin{array}{c}\text { Deviation } \\
\text { Standard }\end{array}$ \\
\hline RPT AR & 0.17 & 0.00 & 0.01 & 0.02 \\
RPT NAR & 0.36 & 0.00 & 0.03 & 0.06 \\
RPT AP & 0.83 & 0.00 & 0.05 & 0.10 \\
RPT NAP & 0.04 & 0.00 & 0.001 & 0.005 \\
BO & 0.99 & 0.32 & 0.57 & 0.21 \\
CS & 33.9 & 0.00 & 27.8 & 5.46 \\
AQ & 1.00 & 0.00 & 0.43 & 0.49 \\
LV & 9.23 & 0.009 & 0.77 & 0.87 \\
\hline
\end{tabular}

Result of descriptive statistics shows that tunnelling related party transactions that are proxied with accounts receivable on the related party (RPT AR) explains average value 0.01 or 1 percent, which means during the period of 2017-2019 the financial industries, averagely, perform related party transactions that are related to accounts receivable for 1 percent from their total assets. Related party transactions other than accounts receivable (RPT NAR) has average value of 3 percent from the total assets. It means that the level of financial companies in implementing tunnelling related party 
transactions with the proxy of related party transactions other than accounts receivable during 20172019 averagely has 3 percent value of the total assets. Propping that is proxied with related party transactions which is related to accounts payable (RPT AP) has average value of 5 percent. It means, during 2017-2019 financial companies perform related party transactions that is related to accounts payable averagely 5 percent from the liabilities amount and that amount is still considered low. While for related party transaction related to liabilities other than accounts payable is 0.1 percent so that it can be interpreted that financial companies during 2017-2019 implement related party transaction related to liabilities other than accounts payable for 0.1 percent from total liabilities. Table 3 shows that blockholder ownership as the independent variable has average value of 0.57 which reflects that most of total shareholdings of financial sector companies are owned by certain parties. Control variable of company size has average value of 27.8 and leverage average value for 0.77 which means the number of liabilities of financial companies is lower when it is compared to the total assets. Meanwhile, it is also found that 44 percent of financial sector companies use Big Four PAF as their external auditors.

\section{Classic Assumption Test}

This study uses four classic assumption tests, they are normality test, multicollinearity test, heteroscedasticity test, and autocorrelation test. This study passes the classical assumption test except normality test and autocorrelation test. Normality test by using Jarque-Bera shows that the samples are not distributed normally. Nevertheless, Central Limit Theorem (CLT) random sampling taken of more than 30 can be said that they were distributed normally. Furthermore, the larger the sample size then normal distribution will be higher (Islam, 2018). Besides that, although there is positive autocorrelation, if the test uses random effect regression model then it should not be a problem (Kosmaryati et al., 2019). The result is shown in Table 4.

Table 4. Result of Classic Assumption Test

\begin{tabular}{lcccc}
\hline \multicolumn{1}{c}{ Test Type } & RPT AR & RPT NAR & RPT AP & RPT NAP \\
\hline $\begin{array}{l}\text { Normality Test } \\
\text { (Jarque-Bera }\end{array}$ & 1200,937 & 632,8055 & 1003,193 & 2110,769 \\
Probability) & $\begin{array}{c}\text { (Data are not } \\
\text { distributed } \\
\text { normally) }\end{array}$ & $\begin{array}{c}\text { (Data are not } \\
\text { distributed } \\
\text { normally) }\end{array}$ & $\begin{array}{c}\text { (Data are not } \\
\text { distributed } \\
\text { normally) }\end{array}$ & $\begin{array}{c}\text { (Data are not } \\
\text { distributed } \\
\text { normally) }\end{array}$ \\
$\begin{array}{l}\text { Multicollinearity } \\
\text { Test (Correlation }\end{array}$ & Multicollinearity & Multicollinearity & Multicollinearity & Multicollinearity \\
Value $>$ 0,08) & There is not & There is not & There is not \\
Heteroscedasticity & There is not & There is not & There is not & There is not \\
Test & Heteroscedasticity & Heteroscedasticity & Heteroscedasticity & Heteroscedasticity \\
(Glejser Test) & symptom & symptom & symptom & symptom \\
Autocorrelation & 1,720 & 1,374 & 1,374 & 1,374 \\
Test (Durbin- & (Positive & (Positive & (Positive & (Positive \\
Watson value) & Autocorrelation) & Autocorrelation) & Autocorrelation) & Autocorrelation) \\
\hline
\end{tabular}

\section{Panel Data Regression Estimation Test}

Before panel data regression test, panel data regression estimation test was performed first and it is included Common Effect Model (CE), Fixed Effect Model (FE), and Random Effect Model (RE) (Winarno, 2015, 9.14-9.27). Panel data regression estimation test shows that the most appropriate for panel data regression test in this study is random effect model that is presented in Table 5.

Table 5. Result of Panel Data Regression Model Estimation Technique Test

\begin{tabular}{lcccc}
\hline $\begin{array}{c}\text { Regression } \\
\text { Equation with } \\
\text { dependent } \\
\text { variables }\end{array}$ & $\begin{array}{c}\text { Chow Test } \\
\text { (Cross } \\
\text { section Chi- } \\
\text { square) }\end{array}$ & $\begin{array}{c}\text { Hausman Test } \\
\text { (Cross-section } \\
\text { random) }\end{array}$ & $\begin{array}{c}\text { Langrange } \\
\text { Test } \\
\text { (Breusch- } \\
\text { Pagan, both) }\end{array}$ & $\begin{array}{c}\text { Conclusion of the precise } \\
\text { panel data regression } \\
\text { estimation technique }\end{array}$ \\
\hline RPT AR & 300.6457 & 1.7354 & 77.1322 & Random Effect Model \\
RPT NAR & 350.5622 & 8.2970 & 92.4905 & Random Effect Model \\
RPT AP & 210.3355 & 0.9697 & 35.1900 & Random Effect Model \\
RPT NAP & 387.6408 & 7.2733 & 109.654 & Random Effect Model \\
\hline
\end{tabular}




\section{Hypothesis Test}

Based on random effect model for each of dependent variable, then the summary of hypothesis test with panel data regression is presented in Table 6.

Table 6. Hypothesis Testing Results

\begin{tabular}{lcccccccc}
\hline \multirow{2}{*}{ Variables } & \multicolumn{3}{c}{ RPT TUNNELING } & \multicolumn{3}{c}{ RPT PROPPING } \\
\cline { 2 - 9 } & \multicolumn{2}{c}{ RPT AR } & \multicolumn{3}{c}{ RPT NAR } & \multicolumn{2}{c}{ RPT AP } & \multicolumn{2}{c}{ RPT NAP } \\
\cline { 2 - 9 } & $\begin{array}{c}\text { Regression } \\
\text { coefficient }\end{array}$ & Prob & $\begin{array}{c}\text { regression } \\
\text { coefficient }\end{array}$ & Prob & $\begin{array}{c}\text { regression } \\
\text { coefficient }\end{array}$ & Prob & regression \\
coefficient & Prob \\
\hline Constanta & -0.001 & 0.435 & 0.094 & 0.000 & -0.003 & 0.458 & -0.000 & 0.219 \\
BO & 0.016 & 0.029 & 0.045 & 0.017 & -0.006 & 0.392 & 0.063 & 0.262 \\
UP & 0.000 & 0.397 & -0.001 & 0.051 & 0.000 & 0.459 & 0.000 & 0.152 \\
KA & 0.005 & 0.048 & -0.003 & 0.353 & 0.010 & 0.168 & 0.000 & 0.002 \\
LV & 0.000 & 0.479 & -0.069 & 0.000 & 0.068 & 0.001 & 0.000 & 0.237 \\
$\mathrm{R}^{2}$ & 0.032 & & 0.103 & & 0.047 & & 0.047 & \\
Adjusted & 0.016 & & 0.088 & & 0.031 & & 0.031 & \\
$R^{2}$ & & & & & & & & \\
F-statistic & 1.964 & 0.050 & 6.824 & 0.000 & 2.881 & 0.011 & 2.914 & 0.001 \\
\hline
\end{tabular}

Table 6 shows that value of adjusted $R^{2}$ for dependent variable of related party transactions related to accounts receivable (RPT AR) is 1.6 percent. It means, independent variables are blockholder ownership, company size, audit quality, and leverage statistically able to explain variant proportions of the related party transactions related to accounts receivable for 1.6 percent and the rest ( 98.4 percent) is explained by other variables outside of this study. Likewise, for the dependent variables test result of other related party transactions (RPT NAR, RPT AP, and RPT NAP) it was found to have adjusted $R^{2}$ value between 3.1 - 8.8 percent. It means that independent variables, which are blockholder ownership, company size, audit quality, and leverage statistically able to describe variant proportions of those related party transactions for $3.1-8.8$ percent and the rest (91.2 - 96.9 percent) are explained by other variables outside of this study. Hypothesis test result also shows value of F-statistic for the four tests, they are related party transactions related to accounts receivable (RPT AR), assets other than receivable (RPT NAR), accounts payable (RPT APR), and liabilities other than accounts payable (RPT NAP) have lower probability value of 0.05 percent, so that, simultaneously, independent variables significantly affect dependent variables. It also indicates that this research model meets goodness of fit as well so that it is feasible to use for hypothesis testing.

$\mathrm{T}$ test result (partial test) indicates that blockholder ownership variable has positive regression coefficient for 0.016 percent and 0.045 at a significance level of less than 5 percent for RPT AR and RPT NAR dependent variables. It means that blockholder ownership has positive effect on related party transactions related to account receivable assets (RPT AR) and related party transactions other than accounts receivable (RPT NAR) which is the proxy of tunneling. The bigger blockholder ownership then the more tunneling related party transactions, which is related to accounts receivable or other than accounts receivable. Meanwhile, $t$ test result indicates that blockholder ownership doesn't affect significantly to propping that is proxied by related party transactions related to accounts payable (RPT $\mathrm{AP}$ ) and other than accounts payable (RPT NAP). It is seen from the value of regression coefficient for those variables which is -0.007 and 0.064 with level of significance more than 5 percent. Therefore, the first hypothesis is supported for tunneling related party transactions dependent variables but it is not supported for related party related to propping.

Table 6 also presents the value of adjusted $R^{2}$ dependent variable of tunneling related party transactions, which are accounts receivable and other than accounts receivable for 10.4 percent (1.6 plus 8.8 percent). This value is higher than the value of adjusted $R^{2}$ propping related party transactions, the accounts payable and other than accounts payable, for 6.2 percent ( 3.1 percent plus 3.1 percent). This means that the effect of blockholder ownership on tunneling related party transactions is bigger than propping related party transactions. Thus the second hypothesis is supported. For the control variable, company size doesn't effect on the tunneling or propping related party transactions. Audit quality is proven to have positive effect on related party transactions related to accounts receivable (RPT AR) and related party transactions related to liabilities other than accounts payable. However, audit quality does not affect related party transactions other than accounts receivable (RPT NAR) and related party transactions related to accounts payable (RPT AP). In relation to leverage, this control variable is proven 
only affect related party transactions related to assets other than accounts receivable and accounts payable.

\section{Discussion}

The first hypothesis is that blockholder ownership has a positive effect on related party transactions. Based on the results of the research regression, blockholder ownership has a significant positive effect on tunnelling related party transactions which are proxied by related party transactions related to receivables and assets other than receivables. This means that the higher the share ownership of the company by certain parties, the more transactions related to related parties related to trade receivables and assets other than trade receivables are carried out by the financial industry. The test results support the research which shows that the ownership structure has a positive influence on the possibility of related party transactions (Yeh et al., 2012). When the ownership structure of the financial industry becomes more concentrated, the higher the number of related party transactions related to assets other than receivables. Party transactions can occur because there is a contract between the director and blockholder ownership, so that the party has influence for the company to conduct related party transactions to maximize personal profits (Dewi, 2010). The results of this study are in line with agency theory that concentrated ownership is vulnerable to the takeover of the interests of minority shareholders by the majority shareholder (blockholder ownership) through related party transactions (Supatmi et al., 2019).

On the other hand, this study fails to prove that blockholder ownership has an effect on propping related party transactions which are proxied by related party transactions related to trade payables and liabilities other than trade payables. Propping is the provision of bailout assets or with the help of liquidity from blockholder ownership to the company (Friedman et al., 2003). The hypothesis is rejected because the object of this research is the financial industry so as to avoid dependence on funding from other parties and avoid the emergence of conflicts of interest between shareholders in accordance with 0JK Regulation Number IX.E.1 of 2009 concerning Affiliated Transactions and Conflicts of Interest in Certain Transactions. Although the results of the study fail to prove the effect of blockholder ownership on the two dependent variables, these results are in line with previous research which stated that ownership structure was not proven to have an effect on the size of related party transactions related to liabilities (Utama, 2015).

The second hypothesis of this research is that the effect of blockholder ownership on tunneling related party transactions is bigger than propping related party transactions. The results showed that this hypothesis was accepted. The basis of the conclusion is seen from the adjusted R2 value for tunnelling related party transactions is bigger than propping related party transactions. This finding supports the agency theory that for agency conflict type II, namely conflicts between majority and minority shareholders (Villalonga \& Amit, 2006), which also occurs in Indonesia, causing related party transactions conducted by companies in Indonesia, tend to contain more conflicts of interest. compared to its efficiency and also uses more types of tunneling than propping (Supatmi et al., 2019). If the ownership structure is more concentrated, then blockholder ownership will conduct self-dealing transactions which results in the concentration of ownership in the amount of related party transactions being dominated by abusive related party transactions (Utama, 2015). When the ownership structure is increasingly concentrated, it will harm minority shareholders by conducting tunneling actions (Agustinah et al., 2019). This finding supports the research that blockholder ownership in Chinese companies uses tunneling and propping to take over the rights of minority shareholders (Cheung et al., 2009). Furthermore, the research also proves that companies in China are more likely to conduct tunneling related party transactions than propping. The results of this study are in line with previous study which state that public companies in Indonesia use a concentrated ownership structure which results in the emergence of many blockholder ownership so that they have more tendency to conduct tunneling related party transactions. assets other than accounts receivable and accounts payable (Sari et al., 2016).

Based on the explanation above, in the financial industries it is proven that blockholder ownership has positive effect on tunneling related party transactions which are proxied by related party transactions of receivables and assets other than receivables. The result also finds that the effect of blockholder ownership on tunnelling related party transactions is bigger than propping related party transactions. This condition may occur because the financial industries avoids dependence on funding from other parties and further increases the distribution of assets to other parties and is more profitable for blockholder ownership. Findings of this study can provide additional empirical evidences for the relevant agency theory about blockholder ownership that affects tunnelling related party transactions and has the potency for the emergence of agency conflicts because the rights of minority shareholders might be taken over. For financial industries, this research result can be taken into consideration in managing 
the composition of the shareholding and to increase monitoring on the transactions that are performed by the financial companies especially for tunnelling related party transactions. For the investors, these findings can be their considerations in conducting their investment especially in financial industries by considering the presence of blockholder ownership and related party transactions because it may affect the rights of the investors. For regulators, especially for Financial Services Authority and Indonesian Bank, these findings can be used as supporting materials in making regulations about related party transactions that is implemented by the financial industries.

Limitation of this study is it uses financial industries as research samples in which they are dominated by banking sectors than any other financial companies, so that there is a possibility for bias among subgroups of financial industries. Although they are included in the financial industries, however, every sub sector of the financial industries has differences and has their own characteristics. This study measures blockholder ownership only based on the number of percentages and ignores characteristics of the blockholder ownership, such as individuals or institutions, domestic or foreign, and others. Suggestion for further research is that it should be more focus on certain sub-sectors of the industry, such as insurance companies or other sub-sectors of the industry in exploring the effect of blockholder ownership on related party transactions. Besides that, the following research may use blockholder ownership measurement by distinguishing their characteristics, such as individuals or institutions, domestic or foreign, and others.

\section{CONCLUSION}

The aim of this study is find out the effect of blockholder ownership to related party transactions in financial industries. Research result indicates that blockholder ownership affect tunneling related party transactions that is proxied with related party transactions related to accounts receivable and assets other than accounts receivable positively. However, blockholder ownership does not affect propping related party transactions that is proxied with related party transaction related to accounts payable and related party transactions related to liabilities other than accounts payable. This study also shows that blockholder ownership has more effect on tunneling (that is proxied with related party transactions related to accounts receivable and assets other than accounts receivable) when it is compared to propping (that is proxied with related party transaction related to payable and liabilities).

\section{REFERENCES}

Agustinah, R., Sumarno, M., \& Mubarok, A. (2019). Pengaruh Corporate Governance, Struktur Kepemilikan, Hak Arus Kas, Dan Disclosure of Rpt Terhadap Transaksi Pihak Berelasi. Multiplier: Jurnal Magister Manajemen, 2(2), 91-109. https: //doi.org/10.24905/mlt.v2i2.1294.

Bona-Sánchez, C., Fernández-Senra, C. L., \& Pérez-Alemán, J. (2017). Related-party Transactions, Dominant Owners and Firm Value. BRQ Business Research Quarterly, 20(1), 4-17. https://doi.org/10.1016/j.brq.2016.07.002.

Brundy, E. P., \& Siswantaya, I. G. (2014). Pengaruh Mekanisme Pengawasan Terhadap Aktivitas Tunneling. E-Journal UAJY,1-15. http://e-journal.uajy.ac.id/5624/1/Jurnal Ilmiah - Edwin.pdf.

Cheung, Y. L., Jing, L., Lu, T., Rau, P. R., \& Stouraitis, A. (2009). Tunneling and propping up: An analysis of related party transactions by Chinese listed companies. Pacific Basin Finance Journal, 17(3), 372393. https://doi.org/10.1016/j.pacfin.2008.10.001.

Dewi, N. A. C. (2010). Faktor-Faktor yang Mempengaruhi Praktik Ekspropriasi di Indonesia. Jurnal Ilmiah Mahasiswa FEB, 3(1). https://jimfeb.ub.ac.id/index.php/jimfeb/article/view/1404.

Friedman, E., Johnson, S., \& Mitton, T. (2003). Propping and tunneling. Journal of Comparative Economics, 31(4), 732-750. https://doi.org/10.1016/j.jce.2003.08.004.

Helena, R., \& Firmansyah, A. (2018). Pengungkapan Pihak-Pihak Berelasi pada Perusahaan-Perusahaan Salim Group yang Terdaftar di Bursa Efek Indonesia. Jurnal Online Insan Akuntan, 3(2), 185-196. http://www.ejournal-binainsani.ac.id/index.php/JOIA/article/view/1035.

Herliana, V. (2018). Pengaruh Praktik Corporate Governance Terhadap Besaran Transaksi Pihak Berelasi Dan Kinerja Keuangan Perusahaan. AKUNESA: Jurnal Akuntansi Dan Keuangan, 7(1), 1-20. https: //core.ac.uk/download/pdf/230771075.pdf.

Islam, M. R. (2018). Sample size and its role in Central Limit Theorem (CLT). International Journal of Physics and Mathematics, 4(1), 37-47. https://doi.org/10.31295/pm.v1n1.42.

Kosmaryati, K., Handayani, C. A., Isfahani, R. N., \& Widodo, E. (2019). Faktor-Faktor yang Mempengaruhi Kriminalitas di Indonesia Tahun 2011-2016 dengan Regresi Data Panel. Indonesian Journal of Applied Statistics, 2(1), 10. https://doi.org/10.13057/ijas.v2i1.27932. 
Pangesti, N. G., \& Hidayat, W. (2019). Konsentrasi Kepemilikan, Transaksi Pihak Berelasi, dan Kinerja Perusahaan. E-Jurnal Akuntansi, 29(2), 592. https://doi.org/10.24843/eja.2019.v29.i02.p08.

Sari, R. C., Fatimah, P. L. R., \& Djajadikerta, H. G. (2016). Development of Tunneling Detection Model: A New Corporate Performance Improvement. Jurnal Pengurusan, 48(2016), 33-46. https://doi.org/10.17576/pengurusan-2016-48-03.

Sun, P., Hu, H. W., \& Hillman, A. J. (2016). The Dark Side of Board Political Capital: Enabling Blockholder Rent Appropriation. Academy of Management Journal, 59(5), 1801-1822. https://doi.org/10.5465/amj.2014.0425.

Supatmi. (2020). Pengaruh Transaksi Pihak Berelasi Terhadap Kinerja Perusahaan dengan Koneksi Politik Sebagai Pemoderasi. Universitas Brawijaya.

Supatmi, Sutrisno, T., Saraswati, E., \& Purnomosidhi, B. (2019). The effect of related party transactions on firm performance: The moderating role of political connection in indonesian banking. Business: Theory and Practice, 20(2003), 81-92. https://doi.org/10.3846/BTP.2019.08.

Tambunan, M. E., Siregar, H., Manurung, A. H., \& Priyarsono, D. S. (2013). Transaksi Afiliasi, Grup Bisnis, Pemegang Saham Ultimat, Tata Kelola Perusahaan Yang Baik, Rasio Utang Terhadap Modal.

Utama, C. A. (2015). Penentu Besaran Transaksi Pihak Berelasi: Tata Kelola, Tingkat Pengungkapan, dan Struktur Kepemilikan. Jurnal Akuntansi Dan Keuangan Indonesia, 11(1), 37-54. https://doi.org/10.21002/jaki.2015.03.

Villalonga, B., \& Amit, R. (2006). How do Family Ownership, Control and Management Affect Firm Value? Journal of Financial Economics, 80(2), 385-417. https://doi.org/10.1016/j.jfineco.2004.12.005.

Winarno, W. W. (2015). Analisis ekonometrika dan statistika dengan eviews. UPP STIM YKPN.

Yeh, Y. H., Shu, P. G., \& Su, Y. H. (2012). Related-party transactions and corporate governance: The evidence from the Taiwan stock market. Pacific Basin Finance Journal, 20(5), 755-776. https://doi.org/10.1016/j.pacfin.2012.02.003. 